\title{
Australian Journal of

\section{Interaction between nitrogen and potassium in fertilization of the piatã grass (Urochloa brizantha): productive and phytometric characteristics}

\author{
Edna Maria Bonfim-Silva*,1,2 , Léa Paula Vanessa Xavier Corrêa de Morais ${ }^{2}$, Adriano Bicioni Pacheco ${ }^{1}$, \\ Tonny José Araújo da Silva ${ }^{1}$, Helon Hébano de Freitas Sousa ${ }^{1}$, Éllen Souza do Espirito Santo ${ }^{1}$, Carina \\ Sthefanie Lemes e Lima Bär ${ }^{1}$
}

\author{
${ }^{1}$ Institute of Agricultural Sciences and Technology, Federal University of Mato Grosso, Rondonópolis, Mato Grosso, \\ Brazil \\ ${ }^{2}$ Faculty of Agronomy and Animal Science, Federal University of Mato Grosso, Cuiabá, Mato Grosso, Brazil
}

\section{*Corresponding author: embonfim@hotmail.com}

\section{Abstract}

In this study, the aim was to determine the phytometric and productive features of Urochloa brizantha cv. BRS Piatã cultivated in Oxisol under the influence of the nitrogen and potassium doses applied. The completely randomized experimental design was adopted in a $5 \times 5$ factorial scheme, supplying five doses of nitrogen $\left(0,100,200,300\right.$ and $\left.400 \mathrm{mg} \mathrm{dm}^{-3}\right)$ and five doses of potassium $\left(0,90,180,270\right.$ and $\left.360 \mathrm{mg} \mathrm{dm}^{-3}\right)$, with four replications. Three shoots were cut at 30-day intervals. Plant height, number of leaves, number of tillers, leaf dry mass, stem dry mass and leaf /stem ratio were assessed. The leaf dry mass at the 370,287 and $259 \mathrm{mg}$ $\mathrm{dm}^{-3}$ doses of nitrogen in combination with the $360 \mathrm{mg} \mathrm{dm}^{-3}$ potassium doses revealed the biggest yields $\left(7.8,16.9\right.$ and $\left.11.5 \mathrm{~g} \mathrm{pot}^{-1}\right)$ for the first, second and third cuts, respectively. Therefore, it was revealed that nitrogen and potassium affected the phytometric characteristics in this grass in an isolated manner by doses of nitrogen potassium. The nitrogen and potassium doses interacted positively to present significantly productive characteristics at all the three cutting procedures performed in the Piatã grass when the nitrogen to potassium ratio was maintained at about 1: 1 .

Keywords: leaf/stem ratio, N: K ratio in plants, Urochloa brizantha.

Abbreviations: M.O. Organic Matter, C.E.C. _ Cation Exchange Capacity, V _ Base Saturation, m_ Aluminum Saturation, SAS _ Statistical Analysis System, PH _ Plant Height, $\bar{N} L$ _ Number of leaves, NT_ Number of Tillers, LDM _ Leaf Dry Mass, SDM _ Stem dry mass, and LSR_Leaf-to-stem ratio.

Introduction

Piatã grass (Urochloa brizantha cv. Piatã) is prominent among the forage plants for its exceptional growth rate, the outstanding ability for regrowth and richly available leaves for pasture (Valle et al., 2007). Besides being a good alternative variant from the traditional pasture systems, this cultivar is highly versatile especially for application in the integrated production systems (Almeida et al., 2009; Parizet et al., 2017) and silage production (Epifanio et al., 2014; Epifanio et al., 2016; Parizet al., 2017).

To consolidate its variety of applications, basic soil fertility must first be investigated. This facilitates the perception of a clear picture of the nutrient supply and the ways it can affect the structural and productive characteristics of Piatã grass, to draw up suitable management programs.

Soil fertility is greatly affected by the interactions between the principal nutrients, viz., nitrogen and potassium, which are significant for plant growth. The plant growth spurt in response to the addition of nitrogen necessitates that a nutritional balance is struck with the potassium in the soil; if this does not occur, the availability of this nutrient can become deficient due to dilution, affecting the physiological functions of both nutrients (Cantarella, 2007).
Nitrogen governs several functions and is present as a major constituent of proteins and enzymes, chlorophyll and nucleic acids; besides, it plays a pivotal role in hormone synthesis. Apart from nitrogen, potassium which is the cation found in the highest concentration in plants is responsible for pertinent physiological and metabolic functions, including enzymatic activation, photosynthesis, the translocation of assimilates and osmotic control (Taiz \& Zeiger, 2013).

The increased nitrogen fertilization boosts forage output, producing a higher stem percentage by introducing changes in the structural features, which may result in losses for animal grazing (Carvalho et al., 2017). However, the increased potassium fertilization provides improvements in terms of the productive and phytometric characteristics, as potassium plays significant roles in the synthesis, conversion, and allocation of the metabolites, and maintains the nutritional balance.

In light of the facts mentioned above, the aim of this study is to assess the productive and phytometric characteristics of Urochloa brizantha cV. BRS Piatã in response to the interaction of nitrogen and potassium doses supplied to the Oxisol. 


\section{Results and discussion}

\section{Plant height}

For the plant height variable, an isolated significance was noted for the nitrogen doses in all three cuts and for the potassium only in the third cut. For the nitrogen fertilization, an adjustment was made to the quadratic model of regression for the first and third cuts, at which point the nitrogen levels of 183 and $242 \mathrm{mg} \mathrm{dm}^{-3}$ produced the tallest plant height $(47.3$ and $41.8 \mathrm{~cm})$, respectively; in the second cut $(46.5 \mathrm{~cm})$, at the nitrogen dose of $400 \mathrm{mg} \mathrm{dm}^{-3}$, an increase of $16 \%$ was recorded in comparison to the lack of nitrogen fertilization (Fig. 1A, B, C, D, and E). The plants grown with the addition of nitrogen fertilizer revealed only marginal development and extensive chlorosis (Fig. 1C and $E)$, implying that the organic matter present in the soil was insufficient to satisfy the nitrogen demand of the Piatã grass. In response to the potassium doses, an isolated significance was noted for plant height after the third cut, where an adjustment to the quadratic regression model was made. The highest plant height $(41.3 \mathrm{~cm})$ was recorded at the dose of $215 \mathrm{mg} \mathrm{dm}^{-3}$ of potassium, which is translated as a $32 \%$ increase when compared with the lack of potassium fertilization.

Oliveira et al. (2017) in their study on Xaraés Grass (Brachiaria brizantha) subjected the plants to water slides as well as nitrogen and potassium doses, and reported in plant height increase, besides noting that fertilization increased the effect of water used.

Plant height is among the chief criteria used for a reasonable pasture management to ascertain animal entry and exit in the region (Barbosa et al., 2007; Pedreira et al., 2007). According to Euclides et al. (2016) canopy structure plays a role in the variations observed in the grazing process, leaf accessibility and eases of harvest, and moderates the forage consumption efficiency and animal behavior.

For the number of leaves, a notable interaction was recognized between the nitrogen and potassium doses in all the three cuts. In all the cuts, it was evident that on the response surfaces the nitrogen exhibited quadratic behavior, whereas the potassium increased the linear behavior.

\section{Number of leaves}

The greatest numbers of leaves $\left(87,112\right.$ and 121 leaves pot $^{-}$ $\left.{ }^{1}\right)$ were observed for the 322, 282 and $245 \mathrm{mg} \mathrm{dm}^{-3}$ doses of nitrogen in combination with the potassium dose of $360 \mathrm{mg}$ $\mathrm{dm}^{-3}$, showing a rise of 55,62 and $47 \%$ for the first, second and third cuts, respectively, when compared with the lack of adding nitrogen and potassium fertilizers (Fig. 2).

In their report, Silva et al. (2009) noted that as the nitrogen fertilization increased there was a corresponding decrease in the time of the appearance of new leaves arising from an increased production of new cells, indicating the multiplication of leaf units. In fact, Rodrigues et al. (2008) and Medica et al. (2017) proposed that leaves are highly significant for the productive system, as they are the chief photosynthetic organs and the primary nutrient source for grazing ruminants.

The number of tillers displayed a remarkable interaction between the nitrogen and potassium doses at the time of all the three cuts. While the response surfaces showed the nitrogen doses for the maximum yields, the experimental interval for the potassium doses was insufficient to reach the peak responses.

\section{Number of tillers}

The nitrogen doses of 318, 269 and $234 \mathrm{mg} \mathrm{dm}^{-3}$ in combination with the potassium dose of $360 \mathrm{mg} \mathrm{dm}^{-3}$ registered the greatest yields $\left(20,32\right.$ and 33 pot $^{-1}$ tillers), marking a rise of 52,57 and $42 \%$ for the first, second and third cuts, respectively, when compared with the lack of fertilization using nitrogen and potassium (Fig. 3).

The findings reported for the number of tillers concur with the observations of Costa et al. (2016) who studied Brachiaria brizantha cv. Marandu in Yellow Latosol soil, and recorded the escalation in the number of tillers produced in response to the increased nitrogen fertilization. Lavres Junior \& Monteiro (2003) recorded a notable interaction between the doses of the nitrogen and potassium fertilizer supplied, on the tillering in Mombaça Grass (Panicum maximum).

Silva et al. (2009) emphasized that as the number of tillers rose, apart from directly increasing the dry matter, they enhanced the soil cover through forage and minimized the soil deterioration by decreasing the impact of rainfall and exposure to sunlight. Therefore, the wise management of pasture fertilization boosts soil conservation.

\section{Leaf dry mass}

For the dry mass of leaves, a strong interaction was identified between the nitrogen and potassium fertilization in all the three cuts. During the first and third cuts, the nitrogen doses of 370 and $259 \mathrm{mg} \mathrm{dm}^{-3}$ combined with the potassium dose of $360 \mathrm{mg} \mathrm{dm}^{-3}$ revealed peak yields ( 7.8 and $11.5 \mathrm{~g} \mathrm{pot}^{-1}$ ), with 64 and $63 \%$ increases, respectively, when compared with the lack of fertilization using nitrogen and potassium (Fig. 4A and B).

At the time of the second cut, the nitrogen and potassium exhibited quadratic behavior, with the combined doses of $287 \mathrm{mg} \mathrm{dm}^{-3}$ of nitrogen and $360 \mathrm{mg} \mathrm{dm}^{-3}$ of potassium, showing the highest dry leaf mass (16.9 $\left.\mathrm{g} \mathrm{pot}^{-1}\right)$, a $79 \%$ increment when compared with the lack of application of nitrogen and potassium fertilizers (Fig. 4B).

Rodrigues et al. (2008) in their work on raising the Xaraés Grass (B. brizantha) in a pot of Oxisol, reported similar findings. They observed a rise in the dry leaf mass with a steady increase up to the nitrogen doses of 177, 176 and 168 $\mathrm{mg} \mathrm{dm}$ in all the three cuts and up to the potassium dose of $60 \mathrm{mg} \mathrm{dm}^{-3}$ in the second cut.

The dry mass of leaves exhibited behavior similar to that of the number of leaves and tillers, denoting that this enhanced production is directly linked to the ability to produce new leaves through the increased number of tillers and the larger storage of photoassimilates.

The potential for leaf generation soared when nitrogen and potassium were plentiful in supply, due to the correct balance of their physiological functions. In the plant, potassium promotes the nitrate transportation to the aerial parts. During photosynthesis, nitrogen plays a crucial role as a component of the chlorophyll, while the potassium controls the opening and closing mechanism of the stomata, 


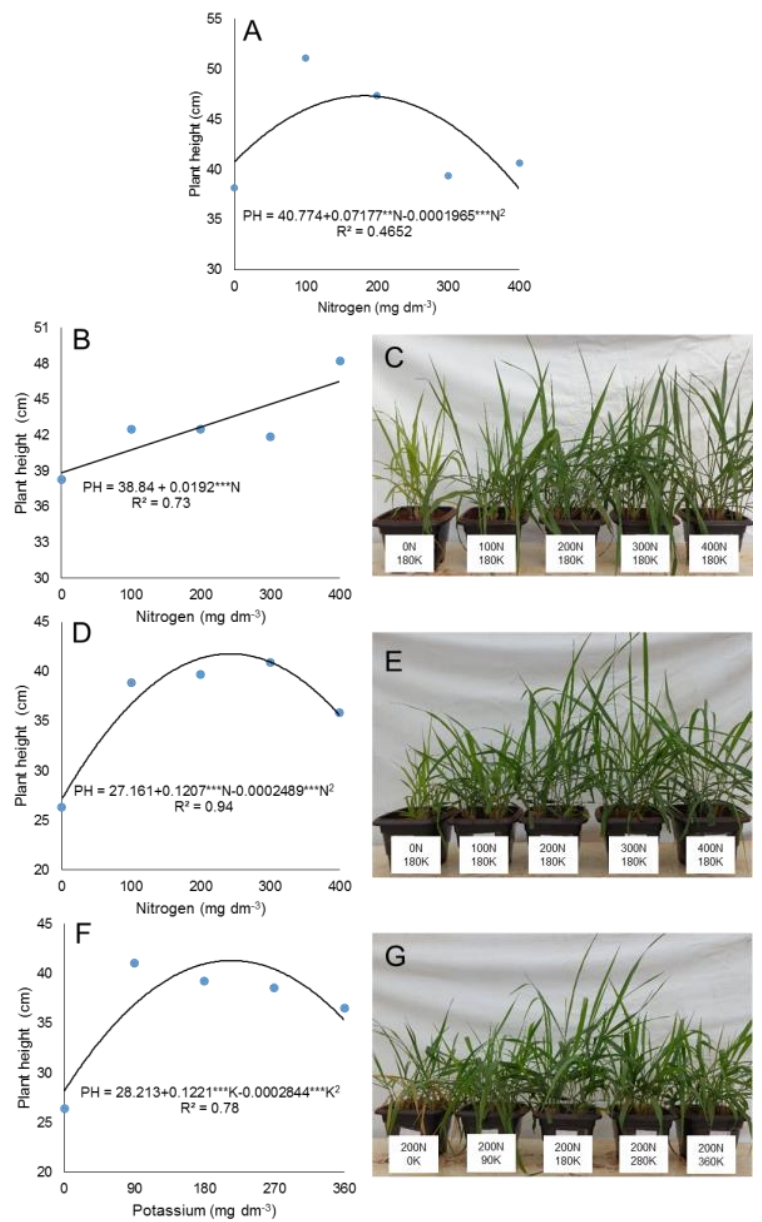

Fig 1. Plant height $(\mathrm{PH})$ of the $U$. brizantha cv. BRS Piatã grass with the supply of nitrogen doses in the first $(\mathrm{A})$, second $(\mathrm{B}, \mathrm{C})$ and third cuts $(\mathrm{D}, \mathrm{E})$ and potassium doses in the third cut $(\mathrm{F}, \mathrm{G}) .{ }^{* * *}$ Significant at $0.1 \%$ probability.

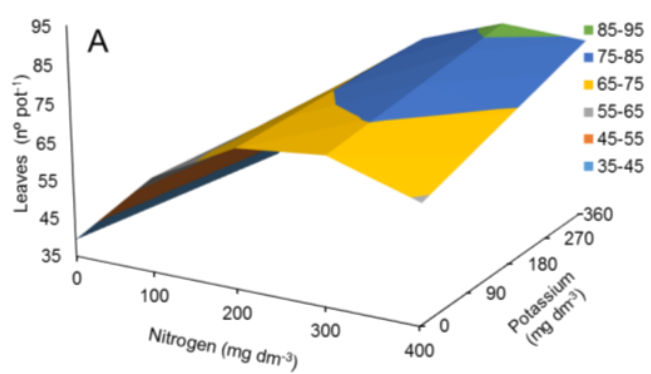

$\mathrm{NL}=39.483+0.24549^{\cdots \cdots} \mathrm{N}-0.0004596^{\cdots \cdots} \mathrm{N}^{2}-0.0000561^{*} \mathrm{~K}^{2}+0.0001407^{\cdots \cdots} \mathrm{NK}$

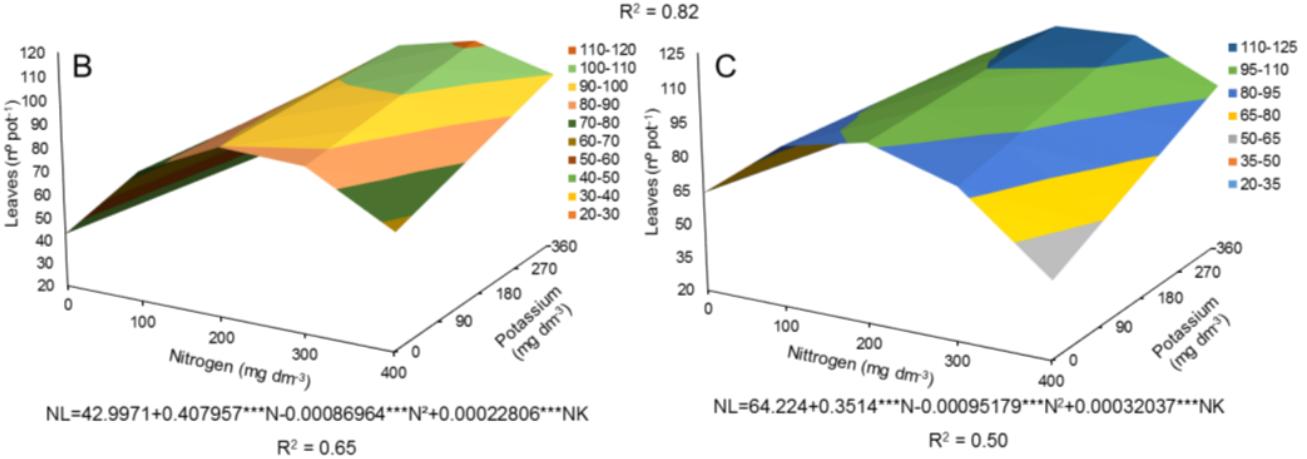

Fig 2. Number of leaves (NL) of the $U$. brizantha cv. BRS Piatã grass supplied with nitrogen and potassium doses in the first (A), second (B) and third cuts (D). ${ }^{*}, * * *$ Significant at 5 and $0.1 \%$ probability, respectively. The colors represent regions of the response variable as a function of nitrogen and potassium doses, as shown in the graph legend. 


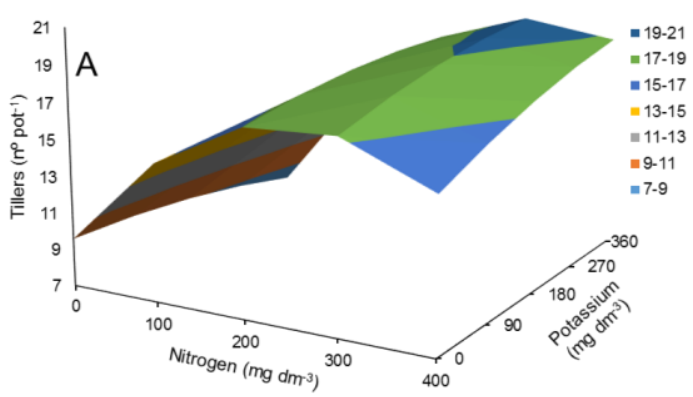

$N T=9.617+0.06026^{* * *} \mathrm{~N}-0.000116^{* * *} \mathrm{~N}^{2}-0.00001335^{*} \mathrm{~K}^{2}+0.00003788^{* * *} \mathrm{NK}$

$$
\mathrm{R}^{2}=0.79
$$

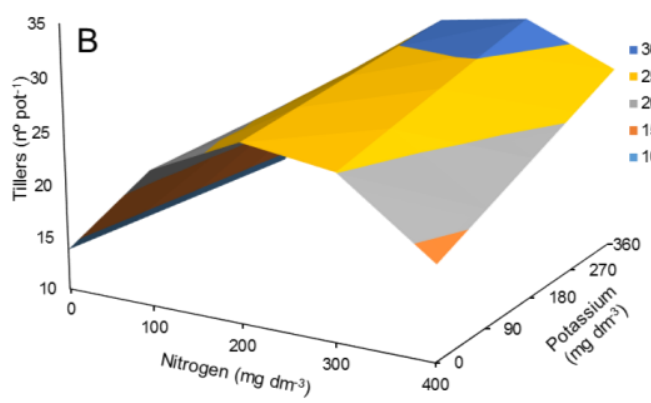

$N T=13.829+0.114261^{* * *} \mathrm{~N}-0.00025607^{* * *} \mathrm{~N}^{2}+0.00006509^{* * *} \mathrm{NK}$ $R^{2}=0.60$

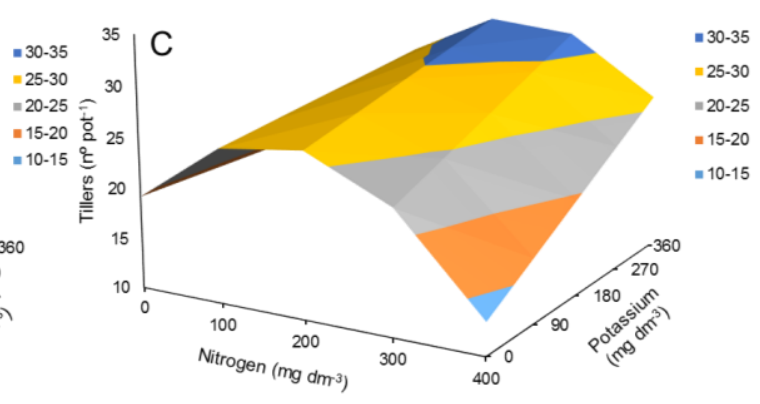

$N T=19.2157+0.084269^{* \star *} \mathrm{~N}-0.00024821^{\star \star *} \mathrm{~N}^{2}+0.0000887^{\star \star *} \mathrm{NK}$

$R^{2}=0.50$

Fig 3. Number of tillers (NT) of the U. brizantha cv. BRS Piatã plants supplied with nitrogen and potassium doses in the first (A), second (B) and third cuts (D). ${ }^{*}, * * *$ Significant at 5 and $0.1 \%$ probability, respectively. The colors represent regions of the response variable as a function of nitrogen and potassium doses, as shown in the graph legend.

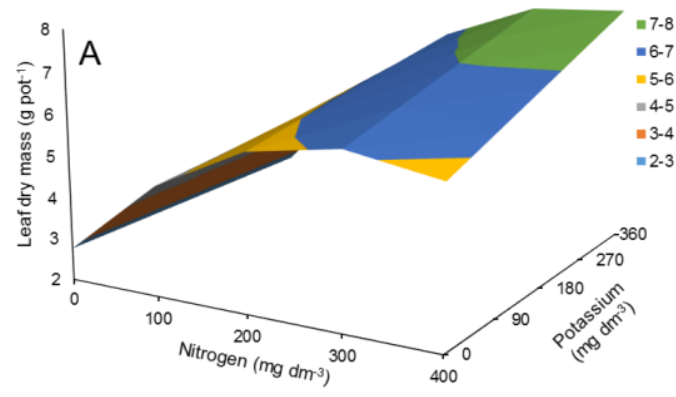

LDM $=2.76974+0.022352^{* \star *} \mathrm{~N}-0.000037195^{\star \star *} \mathrm{~N}^{2}+0.000014327^{* \star N K}$

$$
R^{2}=0.59
$$

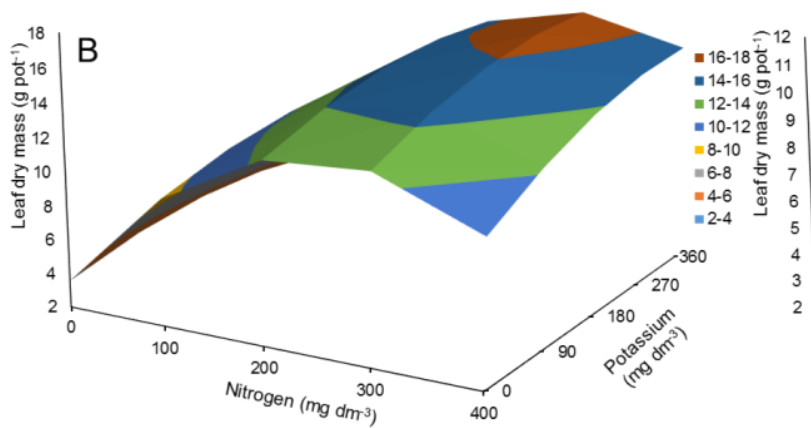

LDM $=3.58+0.0717^{* \star *} \mathrm{~N}+0.016^{*} \mathrm{~K}-0.00014^{\star * *} \mathrm{~N}^{2}-0.000032^{*} \mathrm{~K}^{2}+0.000024^{*} \mathrm{NK}$

$$
\mathrm{R}^{2}=0.78
$$

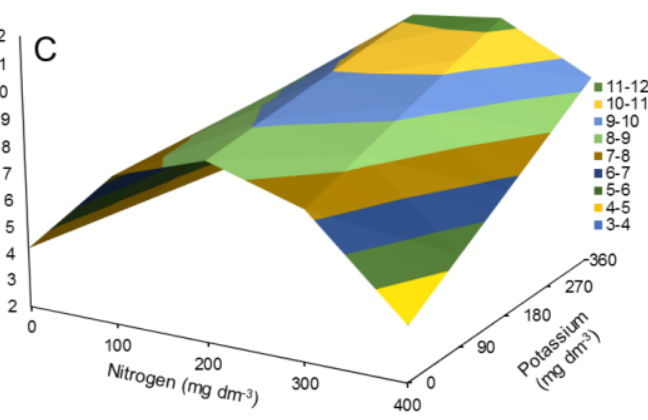

LDM $=4.22297+.04309^{* \star *} \mathrm{~N}-0.00010932^{* \star *} \mathrm{~N}^{2}+0.000037475^{* \star *} \mathrm{NK}$

$$
R^{2}=0.55
$$

Fig 4. Leaf dry mass (LDM) of the $U$. brizantha cv. BRS Piatã grass supplied with nitrogen and potassium doses in the first (A), second (B) and third cuts (D). ${ }^{*}, * *, * *$ Significant at 5,1 and $0.1 \%$ probability, respectively. The colors represent regions of the response variable as a function of nitrogen and potassium doses, as shown in the graph legend. 


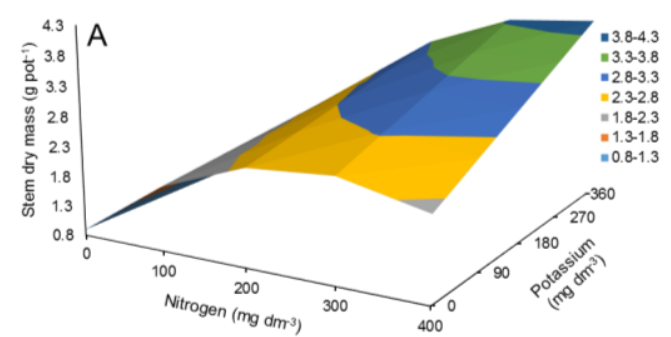

SDM $=0.8987+0.011844^{\cdots \cdots} \mathrm{N}-0.0000215814^{\cdots \cdots} \mathrm{N}^{2}+0.0000123609^{\cdots \cdots} \mathrm{NK}$

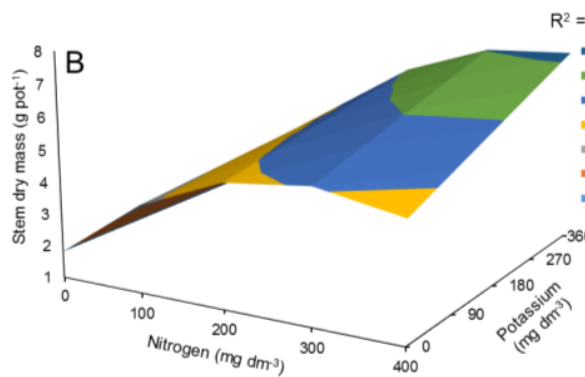

$\mathrm{SDM}=1.8243+0.02266^{\cdots \cdots} \mathrm{N}-0.0000393 \cdots \cdots \mathrm{N}^{2}+0.0000179 \cdots \mathrm{NK}$ $R^{2}=0.60$

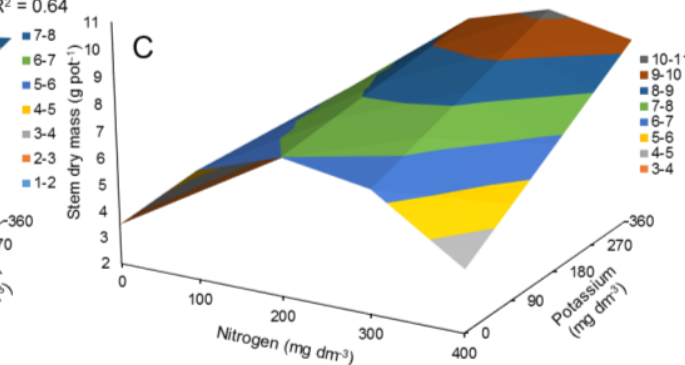

SDM $=3.5098+0.0331 \cdots * N-0.000078429^{* * *} N^{2}+0.000035885^{* * * N K}$ $R^{2}=0.51$

Fig 5. Stem dry mass (SDM) of the U. brizantha cv. BRS Piatã grass supplied with nitrogen and potassium doses in the first (A), second $(B)$ and third cuts $(D) . * * *$ Significant at $0.1 \%$ probability. The colors represent regions of the response variable as a function of nitrogen and potassium doses, as shown in the graph legend.
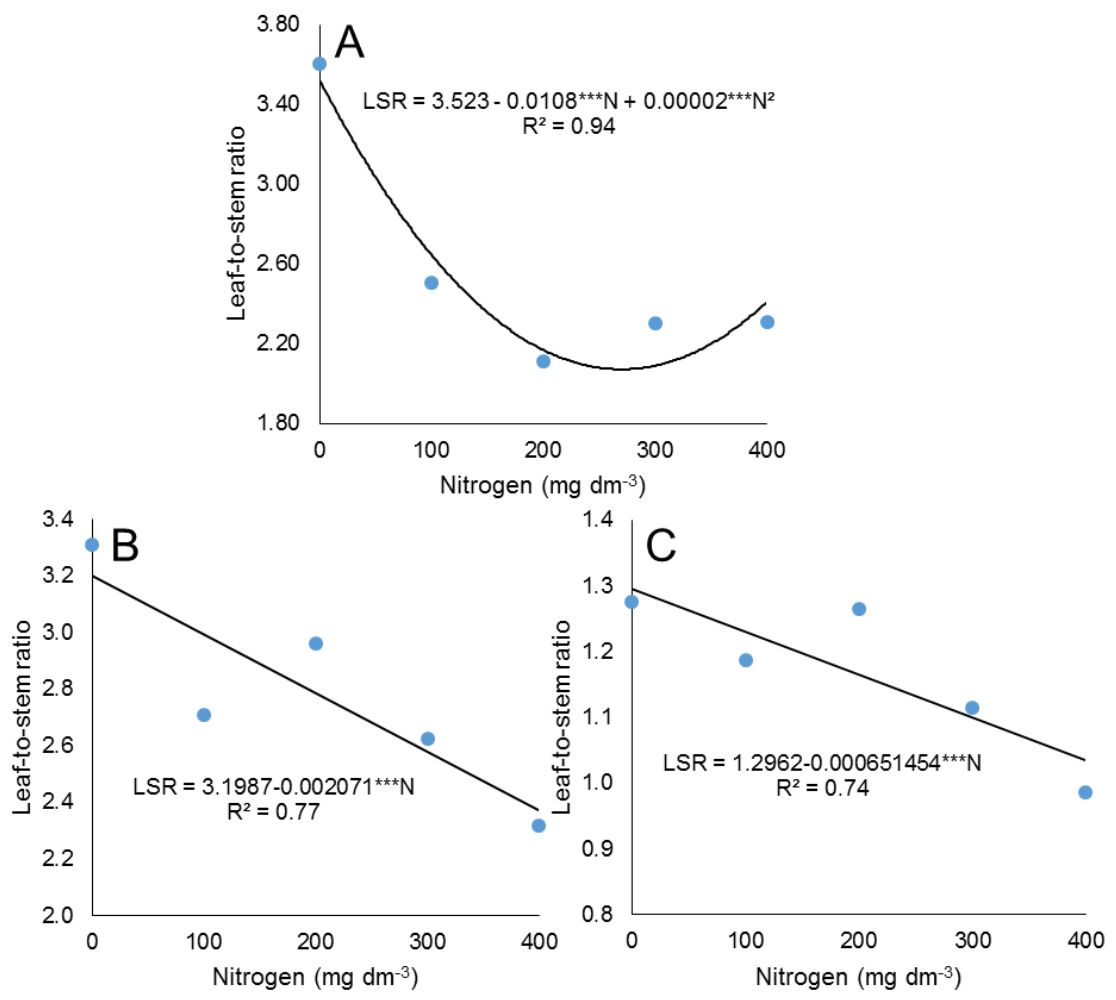

Fig 6. Leaf-to-stem ratio (LSR) of $U$. brizantha cv. BRS Piatã supplied with nitrogen and potassium doses in the first (A), second (B) and third cuts (D). ${ }^{* * *}$ Significant at $0.1 \%$ probability. 
Thus, regulating the entry of carbon dioxide in the right amounts, and improving the generation of carbohydrates through the enhanced photosynthetic efficiency, ultimately resulting in increased shoot production (Taiz \& Zeiger, 2013).

\section{Stem dry mass}

The dry mass of stem showed a clear interaction between the nitrogen and potassium doses in all the three cuts. The nitrogen doses of 377,370 and $293 \mathrm{mg} \mathrm{dm}^{-3}$ acting together with the potassium dose of $360 \mathrm{mg} \mathrm{dm}^{-3}$ provided the maximum yields of stem $\left(3.9,7.2\right.$ and $\left.10.2 \mathrm{~g} \mathrm{pot}^{-1}\right)$, with 77 , 75 and $66 \%$ increases, respectively, when compared with the lack of fertilization using nitrogen and potassium (Fig. 5).

Martuscello et al. (2016) reported identical findings in their investigations in elephant grass (Pennisetum purpureum cv. Cameroon) cultivated in pots using Ultisol. Their observations included the substantial improvement of stem production in response to the increased nitrogen fertilization and the high positive correlation of shoot production with the protein concentration present in the leaves, thus reiterating the vital role played by the stem in supporting the leaves, which are the main plant parts sought after by grazing animals.

\section{Leaf-to-stem ratio}

The leaf-to-stem ratio showed isolated significance for the nitrogen rates in all the three cuts. At the time of the first cut, the rise in the nitrogen fertilization up to the $270 \mathrm{mg}$ $\mathrm{dm}^{-3}$ nitrogen dose induced the lowest leaf/stem ratio (2.1) (Fig. 6A), a $41 \%$ decline when compared with the complete lack of nitrogen fertilization.

During the second and third cuts, the highest nitrogen dose $\left(400 \mathrm{mg} \mathrm{dm}^{-3}\right)$ in the experimental range revealed the lowest ratios (2.4 and 1.03), with decreases of 25 and $20 \%$ respectively, when compared with the lack of nitrogen fertilization, (Fig. 6B and C). Santos et al. (2016) reported that the drop in the leaf/stem ratio may have a direct bearing on the increase in the dry matter yield of pasture stem.

Rodrigues et al. (2008) reported the decrease in the leaf/stem ratio in response to increased nitrogen fertilization, resulting from the improvement in plant growth affected by stem elongation. However, such alterations in the pasture structure may affect the grazing efficiency due to a decrease in the leaf/stem ratio, although the enhanced forage production outweighs this negative effect.

\section{Materials and methods}

\section{Localization and design of experiments}

From March to June 2014 the experiment was performed in a greenhouse at the Federal University of Mato Grosso, Rondonópolis - MT, Brazil, situated at latitude 1627'50" S and longitude of 5034'49" W, at an elevation of $284 \mathrm{~m}$.

The completely randomized experimental design was adopted following a $5 \times 5$ factorial scheme. Five doses of nitrogen $\left(0,100,200,300\right.$ and $\left.400 \mathrm{mg} \mathrm{dm}^{-3}\right)$ and five doses of potassium $\left(0,90,180,270\right.$ and $\left.360 \mathrm{mg} \mathrm{dm}^{-3}\right)$ were supplied, and four replications were done, amounting to a total of 25 treatments and 100 experimental units. Each experimental unit was a pot of soil capacity of $5 \mathrm{dm}^{3}$.

\section{Soil characteristics, fertility, and plant materials}

Oxisol soil samples under Cerrado vegetation were taken from a depth of 0-0.2 m (EMBRAPA, 2013). Chemical and granulometric analyses were done based on the recommendations of EMBRAPA (1997), once the soil was passed through a $2 \mathrm{~mm}$ mesh and sieved. Before transferring the soil to the pots, the soil was sieved through a $4 \mathrm{~mm}$ mesh and homogenized.

The following chemical and granulometric characteristics were evident in the soil: $\mathrm{pH}\left(\mathrm{CaCl}_{2}\right)=4.2 ; \mathrm{P}=1.1 \mathrm{mg} \mathrm{dm}^{-3} ; \mathrm{K}$ $=29 \mathrm{mg} \mathrm{dm}^{-3} ; \mathrm{Ca}=0.6 \mathrm{cmol}_{\mathrm{c}} \mathrm{dm}^{-3} ; \mathrm{Mg}=0.3 \mathrm{cmol}_{\mathrm{c}} \mathrm{dm}^{-3} ; \mathrm{Al}=$ $0.5 \mathrm{cmol}_{\mathrm{c}} \mathrm{dm}^{-3} ; \mathrm{H}=5.7 \mathrm{cmol}_{\mathrm{c}} \mathrm{dm}^{-3} ; \mathrm{O} . \mathrm{M} .=28.7 \mathrm{gm}^{-3} ; \mathrm{CEC}=$ $7.3 \mathrm{cmol}_{\mathrm{c}} \mathrm{dm}^{-3} ; \mathrm{V}=13.5 \% ; \mathrm{m}=35 \%$; sand $=549 \mathrm{~g} \mathrm{~kg}^{-1}$; silt $=$ $84 \mathrm{~g} \mathrm{~kg}^{-1}$; clay $=367 \mathrm{~g} \mathrm{~kg}^{-1}$.

Soil acidity was treated by liming using dolomitic limestone (PRNT $80.3 \%$ ) to increase the saturation by bases to $45 \%$ after a 30-day incubation period, all the while maintaining the soil water availability at $60 \%$ of the maximum waterretention capacity of the soil. Soon after planting, phosphate fertilization was accomplished using simple superphosphate at the recommended dose of $280 \mathrm{mg} \mathrm{dm}^{-3}$ of $\mathrm{P}_{2} \mathrm{O}_{5}$, based on the findings of a chemical analysis of the soil (Sousa \& Lobato, 2004).

Fertilization employing nitrogen and potassium was done using urea and potassium chloride, respectively. This process was conducted in three phases, viz., one-third was applied at the time of sowing, while the other two-thirds were added at seven-day intervals, according to the doses prescribed, thus negating the risk of salinization of the soil at higher dosages. During the first and second cuts, the nitrogen and potassium doses were maintained in line with the treatments and administered in three divided doses at seven-day intervals.

The Urochloa brizantha cv. BRS Piatã seeds were sown, at the frequency of 15 seeds per pot, at about $0.05 \mathrm{~m}$ depth. Thinning was done four days after emergence, leaving five plants remaining per pot. Throughout the duration of the experiment, the soil moisture was maintained at $80 \%$ of the maximum water retention capacity, according to the gravimetric method (Bonfim-Silva et al., 2011).

\section{Traits measured and Data analysis}

The first and second cuts were made at $5 \mathrm{~cm}$ from the lap of the plants, while the third cut was done at the soil level (Bonfim-Silva et al., 2007). At each cut, the plant height, number of leaves and tillers, dry mass of leaf and stem and leaf/stem ratio were evaluated. The leaves were separated from the stem after each successive cut and the dry masses were assessed after they were oven-dried in a forced air circulation oven at $65^{\circ} \mathrm{C}$ until constant mass was achieved. The data were submitted to the analysis of variance, and when significant values were noted for the interaction between the nitrogen and potassium doses, the surface response study was conducted. However, significance was isolated by the nutrient polynomial regression studies that were done. All the tests were performed to include $5 \%$ error probability, employing the statistical program Statistical Analysis System (SAS, 2014). 


\section{Conclusion}

Nitrogen and potassium exerted a tremendous effect on the phytometric characteristics of Urochloa brizantha cV. BRS Piatã in an isolated manner by a factor. The nitrogen and potassium doses applied in the ratio of about 1:1 interacted significantly, positively affecting the productive characteristics during all the three cutting processes of the Piatã grass.

\section{Acknowledgments}

The authors thank the Brazilian National Council for Scientific and Technological Development (CNPq) and Coordination for the Improvement of Higher Education Personnel (CAPES) for providing scholarships to the authors.

\section{References}

Almeida RG, Costa JAA, Kichel A, Zimmer A (2009) Taxas e métodos de semeadura para Brachiaria brizantha cv. BRS Piatã em safrinha. Embrapa Gado de Corte. Comunicado técnico. 113. 12 p.

Barbosa RA, Nascimento Júnior D, Euclides VPB, Silva SC, Zimmer AH, Torres Júnior RAA (2007) Capim-tanzânia submetido a combinações entre intensidade e freqüência de pastejo. Pesq Agropec Bras. 42(3): 329-340.

Bonfim-Silva EM, Monteiro FA, Silva TJA (2007) Nitrogênio e enxofre na produção e no uso de água pelo capimbraquiária em degradação. Rev Bras Ciênc Solo. 31(2): 909317.

Bonfim-Silva EM, Silva TJA, Cabral EA, Kroth BE, Rezende D (2011) Desenvolvimento inicial de gramíneas submetidas ao estresse hídrico. Rev Caatinga. 24(2): 180-186.

Cantarella H (2007) Nitrogênio. In: Novais RF, Alvarez VVH, Barros NF, Fontes RLF, Cantarutti RB, Neves JCL. Fertilidade do solo, eds. Viçosa: SBCS. p.375-470.

Carvalho RM, Alves LC, Rodrigues PHM, Souza WD, Ávila AB, Santos MER (2017) Acúmulo de forragem e estrutura do dossel de Capim-Marandu diferido e adubado com nitrogênio. Bol Ind Anim. 74(1): 1-8.

Costa NL, Townsend CR, Fogaça FHS, Magalhães JA, Bendahan AB, Santos FJS (2016) Produtividade de forragem e morfogênese de Brachiaria brizantha cv. Marandu sob níveis de nitrogênio. Pub Med Vet Zoo. 10(10): 721-794.

EMBRAPA (2013). Sistema brasileiro de classificação de solos. Rio de Janeiro: EMBRAPA-SPI. 306 p.

EMBRAPA (1997) Manual de métodos de análise de solo. 2 ed. Rio de Janeiro: EMBRAPA-SPI. $212 \mathrm{p}$.

Epifanio PS, Costa KADP, Guarnieri A, Teixeira DAA, Oliveira SS, Silva VRD (2016) Silage quality of Urochloa brizantha cultivars with levels of campo grande Stylosanthes. Acta Sci Anim Sci. 38(2): 135-142.

Epifanio PS, Costa KDP, Severiano EDC, Cruvinel WS, Bento JC, Perim RC (2014) Fermentative and bromatological characteristics of Piata palisadegrass ensiled with levels of meals from biodiesel industry. Semina: Ciênc Agrár. 35(1): 491-504.
Euclides VPB, Montagner DB, Barbosa RA, Valle CBD, Nantes NN (2016) Animal performance and sward characteristics of two cultivars of Brachiaria brizantha (BRS Paiaguás and BRS Piatã). R Bras Zootec. 45(3): 85-92.

Lavres Junior J, Monteiro FA (2003) Perfilhamento, área foliar e sistema radicular do capim-Mombaça submetido a combinações de doses de nitrogênio e potássio. R Bras Zootec. 32(5): 1068-1075.

Martuscello JA, Majerowicz N, Cunha DNFV, Amorim PL, Braz TGS (2016) Características produtivas e fisiológicas de capim-elefante submetido à adubação nitrogenada. Arch Zootec. 65(252): 565-570.

Medica JAS, Reis NS, Santos MER (2017) Caracterização morfológica em pastos de capim-marandu submetidos a frequências de desfolhação e níveis de adubação. Ci Anim Bras. 18: 1-13.

Oliveira EM, Oliveira Filho JDC, Oliveira RAD, Oliveira RMD, Cecon PR (2017) Determination of xaraés grass quality submitted to irrigation water levels and nitrogen and potassium doses. Eng Agríc. 37(1): 64-74.

Pariz CM, Costa C, Crusciol CAC, Meirelles PRL, Castilhos AM, Andreotti M, Costa NR, Martello JM, Souza DM, Protes VM, Longhini VZ, Franzluebbers AJ (2017) Production, nutrient cycling and soil compaction to grazing of grass companion cropping with corn and soybean. Nutr Cycl Agroecosys. 107(1): 1-20.

Pedreira BC, Pedreira CGS, Silva SC (2007) Estrutura do dossel e acúmulo de forragem de Brachiaria brizantha cultivar Xaraés em resposta a estratégias de pastejo. Pesq Agropec Bras. 42(2): 281-287.

Quintino A, Giolo R, Abreu J, Macedo MC (2016) Características morfogênicas e estruturais do capim-piatã em sistema de integração lavoura-pecuária. Vet Zoo. 23(1):131-138.

Rodrigues RC, Mourão GB, Brennecke K, Luz PHC, Herling VR (2008) Produção de massa seca, relação folha/colmo e alguns índices de crescimento do Brachiaria brizantha cv. Xaraés cultivado com a combinação de doses de nitrogênio e potássio. R Bras Zootec. 37(3): 394-400.

SAS Institute (2014) SAS 9.4 Output delivery system: User's guide. SAS Institute, Cary, USA. 1178 p.

Santos PM, Silva JEC, Santos AC, Santos JGD, Araújo AS, Rodrigues MOD (2016) Resíduo líquido de laticínio como fertilizante para o capim Mombaça. Com Sci. 7(2): 251261.

Silva CD, Bonomo P, Pires AJV, Maranhão CMA, Patês NMS, Santos LC (2009) Características morfogênicas e estruturais de duas espécies de braquiária adubadas com diferentes doses de nitrogênio. R Bras Zootec. 38(4): 657-661.

Sousa DMG, Lobato E (2004) Cerrado: Correção do solo e adubação. Planaltina: EMBRAPA Cerrados. $416 \mathrm{p}$.

Taiz L, Zeiger E (2013) Fisiologia vegetal. 5 ed. Porto Alegre: Artmed. $918 \mathrm{p}$.

Valle $\mathrm{CB}$, Euclides VPB, Valério JR, Macedo MCM, Fernandes $C D$, Dias Filho MB (2007) Brachiaria brizantha cv. Piatã: uma forrageira para diversificação de pastagens tropicais. Seed News. 11(2): 28-30. 